\title{
Sejarah Batik Tanah liek dan Pekerjaan Perempuan Perajin Batik di Kabupaten Dharmasraya
}

\author{
Ella Hutriana Putri ${ }^{1}$, Midawati Midawati ${ }^{1}$ \\ 1Program Studi Magister Ilmu Sejarah, Fakultas Ilmu Budaya, Universitas Andalas \\ Jl. Limau Manis, Kec. Pauh, Kota Padang, Sumatera Barat 25163, Indonesia \\ Email : ellahutriana.unand@gmail.com
}

Received 07 November 2019; Received in revised form 03 January 2020; Accepted 28 February 2020

\begin{abstract}
Abstrak
Batik tanah liek merupakan batik khas yang berasal dari Sumatera Barat. Proses pengerjaan batik tanah liek hampir sama dengan batik pada umumnya namun ada beberapa perbedaan dalam proses pengerjaan dan motif yang digunakan. Dalam proses pengerjaan batik tanah liek proses pencelupan kain ke tanah liat dilakukan untuk mendapatkan warna alami tanah liat. Proses perendaman kedalam tanah liat dilakukan lebih kurang selama seminggu. Untuk mendapatkan hasil yang memuaskan. Semua kegiatan tersebut tidak terlepas dari pekerjaan yang membutuhkan kesabaran dan ketelitian. Sumber daya manusia yang dipakai pada umumnya adalah perempuan yang bekerja paruh waktu untuk mengisi kekosongan waktu setelah mengurus rumah tangganya. Penelitian ini menggunakan metode penelitian kualitatif untuk memahami fenomena sosial yang terjadi di masyarakat dengan cara terjun langsung ke lokasi penelitian. Daerah yang diambil dalam penelitian ini adalah di Kabupaten Dharmasraya. Artikel ini bertujuan untuk menjelaskan pekerja perempuan sebagai perajin dan pengusaha batik yang berkecimpung dengan dunia batik tanah liek sejak 1995.
\end{abstract}

Kata Kunci :Perempuan, batik tanah liek, perajin, pengusaha

\begin{abstract}
Abstrack
Batik tanah liek is a typical batik originating from West Sumatra. The process of working on batik tanah liek is almost the same as batik in general, but there are some differences in the workmanship process and the motifs used. In the process of working on clay batik, the process of dyeing cloth into clay is carried out to obtain the natural color of the clay. The process of soaking into the clay is done more or less for a week. To get satisfying results. All activities are inseparable from work that requires patience and accuracy. Human resources that are used in general are women who work part time to fill the vacancy after managing the household. This study uses qualitative research methods to understand social phenomena that occur in society by jumping directly into the study site. The area taken in this study is in the Dharmasraya Regency. This article aims to describe women workers as batik artisans and entrepreneurs who have been in the liek batik world since 1995.
\end{abstract}

Keywords: Women, batik tanah liek, crafters, entrepreneurs

\section{PENDAHULUAN}

Perempuan dalam dunia ekonomi

penggagas usaha kecil yang

penghasilannya dapat membantu

ekonomi keluarga. Tidak hanya sebagai

penggagas ada banyak perempuan yang

bekerja sebagai tenaga lepas di samping

perannya sebagai seorang anak

perempuan, seorang ibu dan seorang istri. Di dunia kesehatan, pendidikan, pertahanan keamanan, sosial dan budaya banyak bermunculan perempuan-perempuan yang bisa menyamakan posisinya dengan laki-laki dan bahkan ada yang posisinya melebihi kemampuannya sebagai seorang perempuan pada umumnya. Ada sekitar 80 persen perekonomian masyarakat 
didominasi oleh usaha-usaha perekonomian rakyat yang berskala kecil, baik sektor pertanian, perdagangan, kegiatan industri (Zed, 1998).

Di Sumatera Barat banyak sektor yang melibatkan perempuan di dalamnya tidak hanya di perkantoran, dunia perdagangan merupakan sektor yang juga melibatkan perempuan. Kerajinan khas Minangkabau seperti songket, tenun dan bordir merupakan kerajinan yang melibatkan perempuan. Kerajinan merupakan jenis kegiatan nonpertanian yang bersifat produktif, yang tumbuh dan berkembang pada masyarakat pedesaan. Pada mulanya usaha ini dilakukan sebagai usaha sambilan masyarakat, sambil mengisi waktu senggang mereka membuat barang-barang yang dapat bermamfaat dalam kehidupan mereka (Boeke, 1995). Kerajinan yang banyak melibatkan kaum perempuan adalah Industri kerajinan batik. Salah satu yang dikenal adalah batik tanah liek. Perempuan dalam hal ini sebagai pengrajin batik mempunyai peran sebagai pemilik modal, pimpinan perusahaan, pekerja, ataupun pedagang.

Batik tanah liek merupakan jenis batik yang ada di Sumatera Barat selain tenun. Sejak 1995 pemerintah mencanangkan batik tanah liek sebagai batik khas Sumatera Barat. Sehingga sejak 1996 pemerintah Sumatera Barat membiayai sejumlah masyarakat khususnya perempuan kursus membatik hingga ke Solo dan Yogyakarta untuk belajar membatik. Sehingga bekal ilmu yang diperoleh dapat diaplikasikan kedalam bentuk batik yaitu Batik Tanah Liek khas Sumatera Barat.

Proses pembuatan batik di Sumatera Barat pada umumnya dilakukan oleh perempuan mulai dari membuat pola, mencanting, dan memberi warna. Dalam tahapan pemberian warna juga bisa dilakukan oleh laki-laki jika proses pewarnaan dilakukan dalam jumlah banyak. Adapun proses yang tidak bisa dilakukan perempuan adalah proses pembuatan batik cap yang memerlukan tenaga lakilaki. Di Sumatera Barat ada banyak batik yang dikembangkan tidak hanya batik tanah liek tapi juga batik yang seperti dibuat di Jawa tapi menggunakan berbagai motif dari ukiran-ukiran khas Minangkabau maupun menggunakan motif yang terinspirasi dari naskah kuno Minangkabau.

Salah satu orang yang terlibat dalam proses hidupnya kembali batik tanah liek adalah Eni Mulyani. la adalah perempuan keturunan transmigran jawa yang saat itu menetap di Sitiung 1 Kabupaten Dharmasraya. Pengaruh Eni dalam dunia batik tanah liek tidak bisa diragukan. Pada saat pengiriman peserta pelatihan ke Yogyakarta tahun 1995 dikirim 20 orang peserta dari Kabupaten 
HISTORIA : Jurnal Program Studi Pendidikan Sejarah Volume 8 (1) 2020

ISSN 2337-4713 E-ISSN2442-8728

Solok

dan

Kabupaten

pekerjaan. Artinya tidak ada

Sawahlunto/Sijunjung saat itu. Sampai

saat ini sejak pengiriman tersebut hanya

Eni Mulyani yang bertahan walaupun pernah berhenti dari tahun 1996 sampai tahun 2000.

Dalam penelitian ini terdapat beberapa konsep yang digunakan tentang perempuan, tenaga kerja, pengusaha dan batik. Pasal 27 ayat 1 Undang- Undang Dasar 1945 menjelaskan adanya pengakuan terhadap prinsip persamaan bagi seluruh warga negara tanpa kecuali. Prinsip persamaan ini menghapuskan diskriminasi, karenanya setiap warga negara mempunyai hak yang sama di hadapan hukum dan pemerintahan tanpa memandang agama, suku, jenis kelamin kedudukan dan golongan.

Dalam Undang-Undang No 13

Tahun 2003 tentang ketenagakerjaan

Pasal 1 ayat 2 menetukan bahwa tenaga kerja adalah setiap orang yang mampu melakukan pekerjaan guna menghasilkan barang dan/jasa untuk memenuhi kebutuhan sendiri maupun untuk masyarakat. Sedangkan pasal 1 ayat 3 menjelaskan pekerja/buruh setiap orang yang bekerja dengan menerima upah atau imbalan dalam bentuk lain.

Dalam pasal 5 Undang Undang No 13 tahun 2003 dibunyikan setiap tenaga kerja memiliki kesempatan yang sama tanpa diskriminasi untuk memperoleh 
bersangkutan Perempuan dalam kegiatan non pertanian sebagai strategi kelangsungan hidup untuk mengganti pendapatan yang kecil yang berasal dari pertanian atau sebagai jembatan pada waktu sedang tidak ada kegiatan pertanian".

Menurut Biro Statistik di Indonesia dalam buku Ratna Saptari Industri berskala besar adalah Industri yang mempunyai lebih dari 80 orang pekerja, industri berskala sedang memperkerjakan 20-79 pekerja, industri berskala kecil mempunyai pekerja 5-19 orang, industri rumah tangga mempunyai pekerja kurang dari 5 orang. Industri kerajinan batik di Sumatera Barat masuk kepada industri skala sedang dan skala kecil.

Batik adalah proses penulisan gambar atau ragam hias pada media apapun dengan menggunakan lilin batik (wax/ malam) sebagai alat perintang warna, lilin batik (malam) diaplikasikan pada kain untuk mencegah penyerapan warna pada saat proses pewarnaan.

Secara Etimologi, kata batik berasal dari bahasa Jawa "ambhatik" dari kata "amba" berberti lebar, luas, kain; titik berarti titik atau "matik" (kata kerja dalam bahasa jawa berarti membuat titik) dan kemudian berkembang menjadi istilah batik, yang berarti menghubungkan titik-titik menjadi gambar tertentu pada kain yang luas atau lebar (Musman, 2011).
Batik tanah liek merupakan batik khas Minangkabau yang proses pewarnaannya direndam dalam larutan tanah liek, walupun disisi lain tidak menutup kemungkinan menggunakan warna-warna yang dihasilkan alam seperti kulit kayu, bunga-bungaan buahbuahan dan dedaunan.

Dalam membuat batik biasanya perempuan hanya menguasai satu pekerjaan. Jenis pekerjaan yang dilakukan perempuan biasanya Membuat pola atau mola yaitu membuat kerangka di atas kain putih dengan menggunakan pensil. Pemberian Malam atau lilin menggunakan canting, pemberian warna yang di inginkan, proses pencelupan, pelunturan malam dengan menggunakan air panas biasanya dilakukan oleh lakilaki (Trijoto, 2010).

Dalam perkembangan industri batik tanah liek yang ada di Dharmasraya tidak terlepas dari peranan kaum perempuan yang ada disana. Perempuan-perempuan keturunan transmigran jawa yang lahir dan besar di Dhrmasraya merupakan bagian dari masyarakat yang telah beralkuturasi dengan masyarakat dan kerajinan khas minang. Banyak hal yang harus dilakukan agar batik dari Dharmasraya bisa bertahan dalam dunia batik di Sumatera Barat. Berangkat dari hal inilah penulis ingin mengkaji bagaimana perkembangan batik tanah liek dari Dharmasraya bisa eksis dan bertahan 
HISTORIA : Jurnal Program Studi Pendidikan Sejarah Volume 8 (1) 2020

ISSN 2337-4713 E-ISSN2442-8728

sampai saat ini. Bagaimana peran perempuan-perempuan perajin dan pengusahanya bertahan dalam persaingan batik di Sumatera Barat.

\section{METODE}

Metode yang digunakan dalam penulisan ini adalah metode sejarah yang di dalamnya terdapat beberapa langkah yang harus di tempuh yaitu heuristik, kritik, interpretasi, historiografi (Gottschalk, 1975). a). Heuristik adalah pengumpulan data yang dilakukan oeh penulis mengenai perempuan-perempuan pembatik, studi pustaka dan wawancara, b). Kritik dilakukan agar memdapatkan kebenaran sumber, c). Intepretasi berupa penafsiran sumber yang didapat, d). Historiografi yaitu penulisan setelah semua sumber di ditafsirkan. Penelitian ini adalah penelitian kualitatif dengan metode wawancara, observasi, dokumen, dan focus grup discussion (Rahmat, 2009).

\section{HASIL DAN PEMBAHASAN}

\section{Sejarah Batik Tanah Liek}

Pada umumnya batik terkenal dari daerah Jawa dengan berbagai macam motif dan warna. Tidak terlepas dari itu di daerah Sumatera seperti Bengkulu, Jambi dan Sumatera Barat juga mempunyai kain khas deerah masingmasing yang disebut Batik. Bengkulu meyyebut batik dengan nama Batik
Besurek. Jambi menyebut batik dengan nama Batik Jambi. Sumatera Barat menyebut dengan Batik Tanah Liek. Batik tersebut mempunyai ciri dan keunikannya masing-masing.

Di Sumatera Barat batik digunakan oleh perempuan dan laki-laki. Perempuan menggunakan batik tanah liek sebagai kain sandang yang di sandang dibahu yang diselempangkan di dada. Selain kain sandang penggunaan batik tanah liek juga digunakan sebagai lambak yaitu kain yang disarungkan sampai mata kaki (Thaib, 2014).

Dalam buku yang ditukis oleh Widodo BA yang berjudul Batik Tradisional. "Jika ditinjau dari sejarah kebudayaan Prof. Dr. R.M Sutjipto Wirjosuparta menyatakan bahwa sebelum masuknya kebudayaan India bangsa Indonesia telah mengenal tehnik membuat "kain batik". Ditinjau dari design batik dan proses "wav-resist technique" Prof. Dr. Alfred Steinmann mengemukakan, bahwa telah ada semacam batik di Jepang pada zaman dinasti Nara yang disebut "Ro-kechi", di China pada Zaman dinasti T'ang, di Bangkok dan Turkestan Timur. Ditinjau dari sejarah Prof. M. Yamin maupun Prof. Dr. R.M Sutjipto Wirjosuparta mengemukakan bahwa batik di Indonesia telah ada sejak zaman Sriwijaya, Tiongkok pada zaman dinasti Sung dan T'ang (abad 7-9). Kota-kota peghasil batik, antara lain : Pekalongan, 
Solo, Yogyakarta, Lasem, Banyumas, Purbalingga dll. Sebagian masyarakat menganggap Pekalongan, Solo dan Yoyakarta sebagai pusat batik tulis dari masa ke masa" (BA, 1983).

Sejarah batik di Sumatera Barat tidak diketahui kapan dimulainya. Sesuai dengan penemuan yang ada yang dilakukan oleh Prof. Herwandi menyebutkan perkembangan batik yang ada di Sumatera Barat terbagi dari lima periode. Periode pertama Zaman Kerajaan Dharmasraya (13 M) ditandai dengan tinggalan arkeologis yang dijumpai pada patung amoghapasa di Dharamasraya yang mendapatkan kiriman patung dari raja Kertanegara ke Dharmasraya ketika terjadinya peristiwa Pamalayu tahun 1286. Patung tersebut menggambarkan seseorang yang yang diberi pakaian sarung yang dihiasi dengan motif batik, dan di jumpai pula ditempat penemuan patung amoghapasa tersebut sejumlah gerabah yang dihiasi motif bungaan yang dijadikan pola batik di Jawa. Sampai Abad ke-14 saat kerjaan dipindahkan ke Saruaso oleh Adityawarwan batik masih menjadi tempat yang baik denga ditemukannya sebuah prasasti Kuburajo yang dihiasi pola bungaan. Bahkan saat itu juga diperkiran batik tanah liek mulai berkembang.

Pada periode kedua pada masa kerajaan Pagaruyung (16 M) batik diperkirakan sudah tumbuh dan berkembang dipusat kerajaan Pagaruyung. Batik juga didatangkan dari Jawa bahkan Cina. Seiring dengan kemunduran kerjaan Pagaruyung produksi batik juga mengalami pasang surut (Herwandi, 2016).

Periode ketiga pada zaman Belanda (sebelum kemerdekaan) blokade yang dilakukan Belanda di Sumatera Barat menghentikan pasokan kain batik dari Jawa. Sumatera Barat termasuk daerah konsumen batik sejak zaman sebelum Perang Dunia I, terutama batik-batik produksi Pekalongan, Solo, dan Yogyakarta. Meskipun di Sumatera Barat telah berkembang terlebih dahulu industri tenun tangan, tenun Silungkang dan tenun plekat, namun batik tetap digemari masyarakat setempat. Pembatikan mulai berkembang di Padang setelah pendudukan Jepang. Pengembangannya terjadi secara tidak disengaja. Ketika itu akibat blokade Belanda, perdagangan batik menjadi lesu. Karenanya pedagang-pedagang batik yang biasa berhubungan dengan pulau Jawa mencari jalan untuk membuat batik sendiri. Ciri khas dari Batik Padang adalah kebanyakan berwarna hitam, kuning, dan merah ungu dengan pola Banyumasan, Indramayuan, Solo, dan Yogyakarta (Susantio, n.d.).

Pada periode keempat pada masa awal Indonesia merdeka dan 
HISTORIA : Jurnal Program Studi Pendidikan Sejarah Volume 8 (1) 2020

ISSN 2337-4713 E-ISSN2442-8728

periode kelima setelah Indonesia merdeka akhir abad ke-20. Setelah Indonesia merdeka industri batik banyak berkembang di Sumatera Barat ada beberapa orang yang menggiatkan industri batik. akibat blokade-blokade Belanda hubungan antara kedua pulau bertambah sulit. Semua ini. Maka pedagang-pedagang batik yang biasa berhubungan dengan pulau Jawa mencari jalan untuk membuat batik sendiri.

Dengan hasil karya sendiri dan penelitian yang seksama, dari batikbatik yang dibuat di Jawa, ditirulah pembuatan pola-polanya dan diterapkan pada kayu sebagai alat cap. Obat-obat batik yang dipakai juga hasil buatan sendiri yaitu dari tumbuh-tumbuhan seperti mengkudu, kunyit, gambir, damar, dan sebagainya. Bahan kain putihnya diambilkan dari kain putih bekas dan hasil tenun tangan. Perusahaan batik pertama muncul yaitu daerah Sampan Kabupaten Padang Pariaman tahun 1946 antara lain; Bagindo Idris, Sidi Ali, Sidi Zakaria, Sutan Salim, Sutan Sjamsudin dan di Payakumbuh tahun 1948 Sdr. Waslim (asal Pekalongan) dan Sutan Razab (MD, 2016).

Setelah Padang serta kota-kota lainnya menjadi daerah pendudukan tahun 1949, banyak pedagang batik membuka perusahaan/bengkel batik dengan bahannya diperoleh dari
Singapura melalui pelabuhan Padang dan Pakanbaru. Tetapi, setelah hubungan dengan pulau Jawa mulai terbuka kembali, mereka kembali berdagang dan perusahaannya kemudian mati (MD, 2016).

Batik di Sumatera Barat kembali hidup pada periode ke lima tahun 1994 pada masa pemerintahan Hasan Basri Durin sebagai gubernur pada saat itu. Serta kebijakan pemerintah pusat yang saat itu di kuasai oleh Orde Baru. Dalam akhir kebijakan Repelita V dan awal Repelita VI yang saat itu pemerintah cenderung untuk memajukan pertanian dan industri. Dalam bidang pertanian pemerintahan memantapkan swasembada pangan dan meningkatkan produksi pertanian. Sedangkan bidang industri pemerintah memberi kebijakan untuk menghasilkan barang ekspor. Pada Repelita IV peningkatan kualitas sumber daya manusia sebagai pendukungnya sehingga akan terwujud keserasian perkembangan antara sektor pertanian dengan sektor industri dan jasa (Chaniago, 2011).

Pada tahun 1995 sesuai dengan amanat dari Repelita V dan VI di Sumatera Barat salah satu daerah saat itu yakni Kabupaten Sawahlunto/Sijunjung mengirimkan beberapa orang untuk mengikuti pelatihan batik di Solo dan Yogyakarta. Salah satunya adalah Eni Mulyani perempuan keturunan Jawa ini adalah 
salah satu masyarakat Kabupaten Sawahlunto/Sijunjung yang dikirim untuk mengikuti pelatihan batik dan masih eksis sampai saat ini. Pengiriman masyarakat untuk mengikuti pelatihan batik tersebut dimaksudkan untuk mempelajari teknik-teknik membatik untuk mengembangkan industri batik tanah liek khas Sumatera Barat.

Selain Eni Mulayani ada seorang yang ikut mengembangkan batik Tanah Liek di Sumatera Barat. la adalah Wirda Hanim, Wirda Hanim dahulunya merupakan pengusaha bidang kerajinan Sulam dan Bordir. Menurut Wirda Hanim sebelum belajar membatik ke Solo dan Yogyakarta. Batik di Sumatera Barat merupakan barang langka yang harus di rawat dan di jaga. Hal ini terbukti dengan penggunaan batik tanah liek dikalangan penghulu-penghulu dikampungnya pada saat itu. Pemakaian yang hanya sesekali membuat batik tanah liek terlihat langka dan patut di jaga walaupun dalam keadaan lusuh di makan usia.

Berdasarkan waktunya batik di Sumatera Barat tidak diketahui pasti kapan kerajinan batik tanah liek ini muncul, siapa yang pertama kali mulai membatik dan kebenaran apakah batik tanah liek ini memang milik komunal masyarakat Minangkabau (Vernanda, 2018). Teknologi pembuatan batik Minangkabau dari tanah liat merupakan teknologi tertua di Indonesia. Nenek moyang orang Minangkabau datang melalui rute Cina. Mereka berlayar dari daratan Asia (Indo-Cina) mengarungi Laut Cina Selatan, menyebrangi Selat Malaka lalu menyusuri sungai Kampar, Indragiri (Kuantan) dan Siak. Bahkan sebagian dari mereka tinggal di sekitar Kabupaten 50 Koto. Karakter batik Minangkabau lebih mencerminkan motif dari ukiran rumah adat Minang namun yang kerap digunakan adalah sicam, pucuk rebung, siku-siku beragi, kaluak paku (untuk pinggiran kain) dan burung hong.

Namun penggunaan batik Sumatra Barat hanya digunakan untuk acaraacara adat dan biasanya yang memakai pada saat upacara khusus, seperti para pemuka adat seperti Datuak, Bundo Kanduang, raja-raja kecil di Sungai Pagu, Jambu Lipo Punjung, Sawah Lunto, Sijujung dan Solok. Para Datuk memakainya dalam bentuk selendang yang dilingkarkan pada leher. Sedangkan kaum perempuan menyampirkan selendang di bahu.

\section{Perempuan Pelestari Batik}

Pandangan Perempuan Pembatik Terhadap Pekerjaannya. Membatik bukanlah pekerjaan utama perempuan. Pekerjaan utamanya tetap mejadi ibu rumah tangga. Banyak perempuan yang memimpikan bekerja dari rumah sembari tidak meninggalkan pekerjaannya sebagai ibu rumah tangga 
HISTORIA : Jurnal Program Studi Pendidikan Sejarah Volume 8 (1) 2020

ISSN 2337-4713 E-ISSN2442-8728

(Tuwu, 2018). Membatik merupakan pekerjaan yang dikerjakan dalam waktu luang disela-sela kesibukan menjadi ibu rumah tangga. Dalam perekonomian pembatik tidak sepenuhnya mengharapkan penghasilan dari membatik. Dalam satu hari untuk proses memberi lilin pembatik hanya bisa mengerjakan empat sampai lima kain, sedangkan untuk mencanting hanya bisa dikerjakan dua sampai tiga kain. Hal ini tergantung pada berapa pesanan batik yang akan di jual.

Lain lagi jika proses membatik dengan motif yang rumit satu kain bisa dikerjakan dalam waktu satu bulan. Banyak atau tidaknya pesanan akan berdampak pada perekonomian pembatik. Semakin banyak pesanan semakin meningkat pulalah penghasilkan pembatik. Perempuan yang pekerjaan utamanya sebagai pembatik merupakan penghasilan utama baginya. Disela-sela kesibukan menjadi ibu rumah tangga batik menjadi pengasil untuk membantu perekonomian keluarga. Seiring dengan perkembangan zaman, tentu saja peran-peran tersebut tidak semestinya dibakukan, terlebih kondisi ekonomi yang membuatnya tidak bisa menutup mata bahwa kadang-kadang istri pun dituntut untuk harus bekerja sebagai pencari nafkah (Khotimah, 2009). Sebagai seorang perempuan mempunyai banyak tugas sekaligus merupakan hal yang telah biasa dilakukan. Semua pekerjaan rumah tangga dan pekerjaan yang berhubungan dengan usaha harus bergantian dilakukan. Adanya kesempatan perempuan keluar ruang domestiknya dan bekerja keluar rumah atau melakukan kegiatan lain sangat dipengaruhi oleh kesadaran baru dan pergeseran sistem nilai (Dwikurniarini, 2015).

Batik pada era modern seperti saat ini sangat di gandrungi oleh masyarakat luas. Hal ini di dasari oleh semakin giatnya masyarakat memperlihatkan identitas daerahnya melalui batik. Batik dijadikan simbol identitas suatu wilayah. Batik sebagai salah satu produk kerajinan merupakan aset budaya yang perlu dilestarikan. Dalam upaya pelestarian batik yang memiliki aspek artistik, filosofis, ekonomi supaya batik sebagai produk budaya betul-betul membudaya dan diminati oleh masyarakat. Motif-motif yang ada dalam kain batik dijadikan identitas suatu wilayah. Seperti misalnya wilayah pesisir motif yang digunakan adalah motif bergambar binatang laut. Sedangkan batik yang berasal dari wilayah darek banyak menggunakan motif bunga-bungaan dan dedaunan. Batik menjadi salah satu usaha yang terus berkembang pada saat ini.

Perempuan sebagai salah satu penggiat usaha batik terutama batik 
tanah liek menjadi penggerak utama berkembangnya batik tanah liek di Sumatera Barat. Semua kegiatan membatik dikerjakan oleh perempuan mulai dari membuat adonan tanah liat, merendam selama lebih kurang satu minggu, memberi lilin, mencanting, melarutkan lilin, sampai batik tersebut dijual di lakukan oleh perempuan. Membatik bukan hanya sebagai penghasil uang tetapi lebih kepada menciptakan karya seni yang bisa di pakai dan di nikmati banyak orang yang dibuat dengan sabar dan teliti sehingga menghasilkan sesuatu yang patut dibanggakan.

Stereotip yang kuat di masyarakat adalah idealnya suami berperan sebagai pencari nafkah dan pemimpin yang penuh kasih, dan istri menjalankan fungsi pengasuhan anak. Hanya saja, seiring dengan perkembangan zaman, tentu saja peran-peran tersebut tidak semestinya dibakukan, terlebih kondisi ekonomi yang membuatnya tidak bisa menutup mata bahwa kadang-kadang istri pun dituntut untuk harus bekerja sebagai pencari nafkah (Khotimah, 2009).

Sebagai seorang perempuan mempunyai banyak tugas sekaligus merupakan hal yang telah biasa dilakukan. Semua pekerjaan rumah tangga dan pekerjaan yang berhubungan dengan usaha harus bergantian dilakukan. Mempekerjakan pekerja dapat meringankan pekerjaan dalam mengembangkan usaha batik tanah liek. Para pekerja diberikan pelatihan terlebih dahulu sebelum di pekerjakan. Sebagai contoh pekerja hanya memegang dua bidang saja yaitu memberi malam atau lilin dan memcanting warna pada kain. Untuk membuat pola dikerjakan oleh seorang ahli yang biasanya adalah sipemilik usaha tersebut. Sedangkan dalam memberi lilin adalah tugas pengrajin yang di upah berdasarkan upah yang telah ditentukan. Pemberi lilin dan mencanting warna tidak bisa dilakukan oleh orang yang sama. Hal ini dikarenakan masing masing-pembatik mempunyai keahlian masing-masing. Semakin dewasa seseorang maka keterampilannya dibidang tertentu akan meningkat (Dewi, 2012).

Membatik adalah pekerjaan yang membutuhkan kesabaran dan keahlian khusus. Dalam membatik yang paling penting adalah kesabaran dan telaten. Batik tidak bisa dikerjakan terburu-buru supaya mendapatkan hasil yang maksimal. Bagi perempuan pembatik pekerjaanya sebagai pembatik merupakan sebuah kebanggaan tersendiri karena selain bisa menghasilkan uang, batik juga sebagai nilai seni dan identitas daerahnya. Sebagai contoh batik yang dihasilkan di daerah Dharmasraya menggunakan motif tumbuh-tumbuhan dikarenakan daerah 
HISTORIA : Jurnal Program Studi Pendidikan Sejarah Volume 8 (1) 2020

ISSN 2337-4713 E-ISSN2442-8728

tersebut merupakan daerah dataran rendah. Sedangkan di Padang motif batik yang digunakan adalah motif binatang-binatang laut dikarenakan Padang terletak di daerah pesisir pantai barat pulau Sumatera.

Perempuan sebagai pembatik bukanlah suatu pekerjaan utama. Pekerjaan utamanya tetap menjadi ibu rumah tangga. Pekerjaan membatik merupakan pekerjaan untuk membantu suami menambah penghasilan rumah tangga dan mengisi waktu senggang ketika di rumah. Tingkat pendidikan yang sangat rendah mamaksa perempuan untuk memasuki sektor informal yang sangat eksploitatif denga gaji rendah dan jam kerja yang tidak menentu tidak ada cuti dan bayaran penuh (Wibowo, 2011).

Perempuan pembatik tidak bekerja sepanjang hari dan setiap hari. Apabila pesanan sedang banyak mereka mampu memberi lilin ataupun mencanting bisa mengerjakan lima lembar kain batik tanah liek dengan pola besar. Sedangkan proses membatik dengan pola kecil dan rumit satu helai kain mori hanya bisa dikerjakan satu helai kain selama satu bulan bahkan lebih. Gaji yang didapatkanpun tidak terlalu besar dalam prosesi memberi lilin satu helai kain dihargai sebesar Rp. 20.000, - saja sedangkan untuk memberi warna diharga sebesar Rp. 30.000,-.
Upah akan berbeda jika pola gambar kecil dan rumit.

$$
\text { Selain sebagai pembatik }
$$
perempuan ada yang bekerja sebagai pengusaha atau pemilik usaha batik tersebut. Tugas yang diembanpun sangat beraneka ragam, tidak hanya sebagai pembuat pola pada kain, manajemen perusahaan, proses pemasaran dilakukan sendiri baik itu dijual langsung, melalui distributor dan juga pesanan online. Sebagai pemilik usaha yang bertigas mengembangkan usahanya. Perannya juga dituntut sebagai ibu rumah tangga yang pada dasarnya harus menyelesaikan tugas di rumahnya. Peran ganda perempuan ini yang bisa dikatakan kalau perempuan merupakan makluk yang bisa bekerja setiap waktu. Sebagai tambahan penghasilan pundi-pundi keuangan keluarganya.

\section{Kerja Perempuan Dalam Membatik}

\section{Pengusaha}

Pengusaha adalah orang yang mengusahakan (perdagangan, industri dan sebagainya); orang yang berusaha dalam bidang perdagangan. Dalam industri batik banyak tugas yang dilakukan oleh oleh pengusaha. Tugas tersebut meliputi menjalankan tujuan perusahaan, mengawasi usaha yang dibangun, mengatur pekerja atau pengrajin, melakukan promosi penjualan, menciptakan relasi, mengevaluasi penjualan. 
Dalam

mengembangkan

usahanya pengusaha juga harus mempuyai strategi dalam memasarkan produknya. Selain itu pengusaha harus dituntut terus berinovasi dalam hasil karya agar karya yang diciptakan tidak monoton, kaku, dan produk yang dihasilkan tidak mengikuti selera pasar. Inovasi yang dikembangkan bisa berupa jenis kain, pewarnaan alami maupun kimia, pencampuran beberapa motif dalam satu kain. Salah satu contoh strategi pengusaha dalam mengembangkan usaha batiknya adalah bekerjasama dengan pemerintah, sekolah, dan swasta untuk membuat seragam dalam instansi tersebut.

Dalam mengembangkan usahanya pengusaha juga membutuhkan modal tambahan. Modal yang didapatkan oleh pengusaha bisa menggunakan modal pribadi, pinjaman bank dan bantuan dari pemerintah maupun bantuan dari pihak swasta. Selain bantuan berupa pendanaan biasanya pemerintah juga akan mem bantu dalam bentuk promosi seperti diikutsertakan dalam pameran, fashion show, dan sebagainya.

\section{Perajin}

Perajin merupakan merupakan orang yang pekerjaannya membuat barang kerajinan. Tugas utama seorang perajin dalam industri batik adalah membuat batik. Perajin batik biasanya diambil dari orang-orang yang ahli dibidangnya tersebut. Keahlian didapatkan dari berbagai macam kegiatan seperti ikut pelatihan membatik, dan mempunyai latar belakang ilmu dalam membatik seperti tamatan SMSR. Dalam hal membuat batik pekerjaan pembatik diantaranya sebagai berikut.

\section{Membuat pola}

Membuat pola sebelum membuat batik adalah hal pertama yang dilakukan. pembuatan pola diatas kain mori dilakukan dengan menggunakan pensil. Ada dua cara dalam membuat pola batik tulis. Pertama pola dibuat langsung diatas kain, dan yang kedua di ciplak dari selembar kertas. Untuk batik printing sama halnya dengan membuat sablon pada kain, dan untuk batik cap kain mori yang sudah disiapkan langsung dicapkan dan ditunggu beberapa saat hingga kain mori menyerap lilin yang ada pada cap.

Gambar 4. Membuat pola

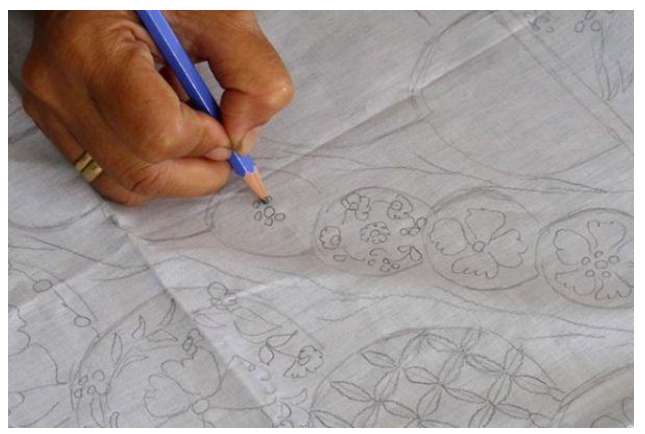

Sumber: $\quad$ www.dewisundari.com di unduh tanggal 6 Oktober 2019

\section{Pemberian lilin/malam}

Proses pemberian lilin merupakan proses awal setelah membuat pola. 
HISTORIA : Jurnal Program Studi Pendidikan Sejarah Volume 8 (1) 2020

ISSN 2337-4713 E-ISSN2442-8728

Guna pemberian lilin adalah menutupi kain supaya warna tidak masuk pada kain yang telah diberi lilin. Proses pemberian lilin bisa memakan waktu hampir dua jam dikarenakan perajin dalam memberi lilin menggunakan tiga canting yang digunakan secara bergantian. Canting tersebut diantaranya canting cecek digunakan pada pola berupa titik-titik, garis-garis halus yang terdapat dalam motif batik. Selanjutnya adalah canting klowongan digunakan untuk motif berukuran agak besar, dan canting tembok digunakan untuk motif batik yang besar.

Gambar 5. Canting Cecek

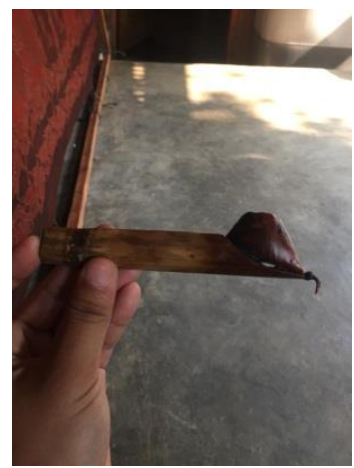

Sumber: Dokumentasi Pribadi Ella Hutriana Putri

\section{Gambar 6. Canting Klowongan}

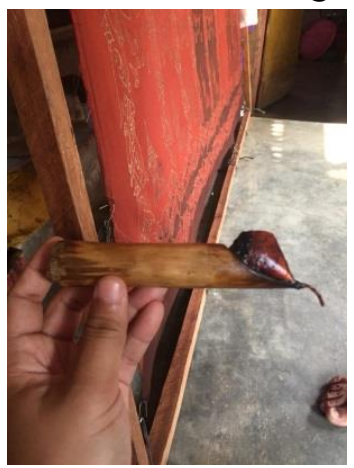

Sumber: Dokumentasi Pribadi Ella Hutriana Putri
Gambar 7. Canting Tembok

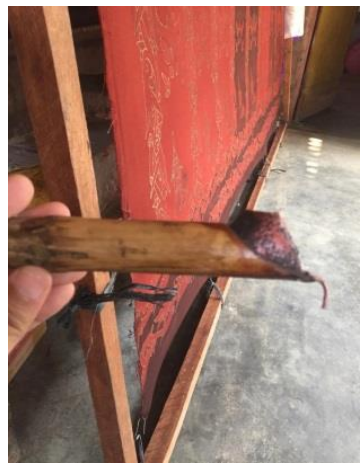

Sumber: Dokumentasi Pribadi Ella Hutriana Putri

\section{Proses pewarnaan}

Proses pewarnaan batik yang dilakukan dengan dua cara yaitu pencelupan dan pencoletan. Pencelupan dilakukan dengan dengan langsung memasukkan kain yang sudah diberi malam/lilin kedalam zat warna

yang yang telah disiapkan, sedangkan pencoletan dilakukan dengan menggunakan kuas atau busa. Zat warna yang digunakan berbeda dengan zat warna yanng digunakan untuk pencelupan.

Gambar 8. Mencolet

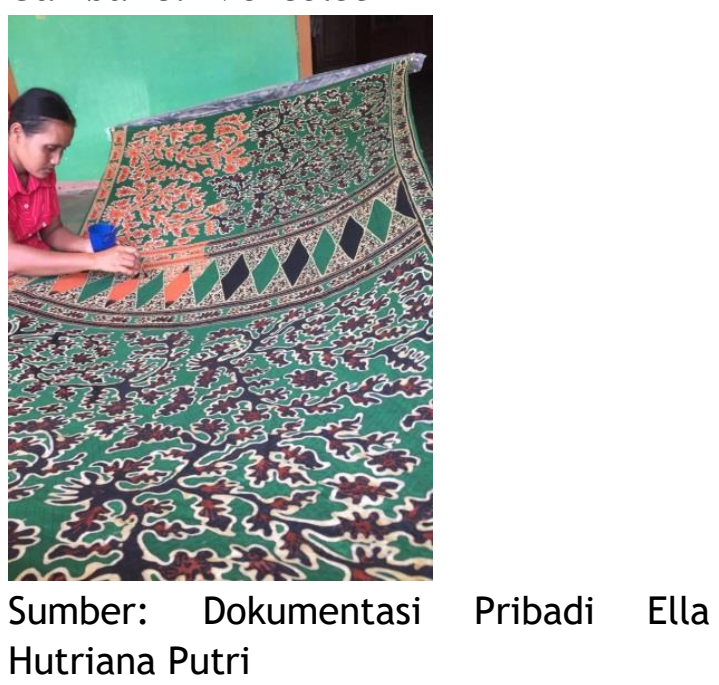


Melorot: Menghilangkan/melepaskan lilin

Proses melorot adalah proses akhir dari mebatik sebelum dijemur. Melorot adalah proses pelepasan lilin yang yang dilakukan diatahap awal. Proses melorot melalui beberapa tahapan

a) Memanaskan air hingga mendidih

b) Memasukkan soda abu sebanyak yang diperlukan

c) Memasukkan kain yang kedalam air mendidih

d) Kain dibolak balik dalam air panas hingga lilin lepas dari kain

e) Setelah bersih bilas dengan air sabun lalu siap untuk dikeringkan.

\section{Jam Kerja}

Perajin batik tidak mempunyai jam kerja yang jelas. Pekerjaan dilakukan sesuai target yang telah ditentukan pengusaha. Biasanya perajin akan memulai pekerjaannya setelah pekerjaan dirumahnya selesai. Beberapa pekerjaan dilakukan dirumah pemilik usaha, dan beberapa lagi bisa dilakukan dirumah masing-masing. Pekerjaan yang dilakukan dirumah pengusaha adalah membuat pola, pencelupan warna, melorot dan menjemur. Sedangkan untuk pekerjaan memberi malam atau lilin dan pencoletan menggunakan kuas dan busa disa dibawa kerumah masingmasing. Dalam satu hari proses pemberian lilin atau,pencoletan warna bisa dikerjakan sampai lima lembar kain dalam sehari. Masing-masing perajin tidak bisa melakukan dua pekerjaan sekaligus. Satu orang perajin hanya akan mengerjakan satu pekerjaan. Seperti memberi malam/lilin saja atau hanya mencolet saja. Biasanya pekerjaan memberi malam atau dan mencolet warna dilakuka oleh perempuan karena dianggap perempuan lebih sabar dan teliti. Sedangkan untuk mencelup warna dan melorot dilakukan oleh laki-laki karena yang dikerjakan banyak kain sekaligus.

\section{PENUTUP}

\section{Kesimpulan}

Batik merupakan batik tanah liek dengan segala kekhasannya yang membuatnya berbeda dengan batikbatik lain yang ada di Indonesia. Batik dari Minangkabau terutama batik tanah liek menjadi warisan komunal masyarakat Minangkabau merupakan yang patut diapresiasi dan dibanggakan sebagai karya seni yang bernilai tinggi. Pemakain batik dalam berbagai acara adat ataupun non formal menambah kebanggan sebagai identitas yang dimiliki masyarakat minang.

Dibalik itu semua batik tidak hanya membanggakan masyarakat Minang tetapi juga sebagai tumpuan hidup banyak orang untuk memperoleh penghasilan dan menambah pendapatan keluarga. Dalam hal ini adalah 
perempuan telaten dan sabar yang berhasil membuat karya seni bernilai tingga. Walaupun bukan sebagai pemasukan tetap tetapi peran ganda perempuan yang membuat mereka bekerja setiap waktu.

\section{Saran}

Berdasarkan penelitian yag dilakukan penulis menemukan beberapa temuan yang dapat dijadikan bahan acuan untuk penelitian dan saran kepada pemerintah daerah. Untuk penelitian berikutnya sejarah batik tanah liek di Sumatera Barat belum selengkap penelitian tentang batik-batik yang berada di Pulau Jawa dikarenakan kurangnya peneliti yang mempunyai minat di bidang sejarah batik. Dalam membuang limbah industri batik perlu diberikan pengetahuan kepada pengusaha dan perajin sebab bisa mempengaruhi lingkungan karena batik selain dibuat dengan warna alam juga dibuat dengan pewarnaan kimia. Kepada pemerintah daerah agar lebih mengembangkan batik tanah liek dengan ciri khas daerah masing-masing termasuk sumber daya manusia dan berupa bantuan modal untuk meningkatkan penghasilan perajin batik.

\section{Daftar Pustaka}

BA, W. (1983). Batik Tradisional. Jakarta: PT Penebar Swadaya.

Boeke, J. H. (1995). Perkapitalisme di Asia. Jakarta: Sinar Harapan.
Chaniago, H. (2011). Hasan Basri Durin: Sebuah Otobiografi. Padang: Yayasan Citra Budaya Indonesia Padang.

Dewi, P. M. (2012). Pastisipasi Tenaga Kerja Perempuan dalam Meningkatkan Pendapatan Keluarga. Jurnal Ekonomi Kuantitatif Terapan.

Dwikurniarini, D.-. (2015). Peranan Perempuan Di Luar Rumah Tangga Dalam Perspektif Historis. MOZAIK: Jurnal Ilmu-Ilmu Sosial Dan Humaniora.

https://doi.org/10.21831/moz.v2i 1.4490

Gottschalk, L. (1975). Mengerti Sejarah Terjemahan Nugroho Notosusanto. Jakarta: Yayasan Penerbit Universitas Indonesia.

Herwandi. (2016). Industri Batik di Sumatera Barat PerspektifSejarah ): Abstrak Sejarah Teknik Membatik di Indonesia: Kebutuhan Pasar Besar namun Kemampuan Produksi Kecil. (524), 1-17.

Khotimah, K. (2009). Diskriminasi Gender Terhadap Perempuan Dalam Sektor Pekerjaan. Yinyang: Jurnal Gender Dan Anak. https://doi.org/10.24090/YY.V4I1. 2009.PP158-180

MD, I. U. (2016). Batik dan Kontribusinya Terhadap Perekonomian Nasional. Jurnal Bestari.

Musman, A. (2011). Batik: Warisan Adiluhung Nusantara. Yogyakarta: G-Media.

Rahmat, P. S. (2009). Penelitian Kualitatif. Journal Equilibrium.

Saptari, R. (1997). Perempuan Kerja dan Perubahan Sosial: Sebuah Pengantar Studi Perempuan. Jakarta: Yayasan Kalyanamitra.

Susantio, D. (n.d.). Sejarah Batik.

Thaib, P. R. R. (2014). Pakaian Adat Perempuan Minangkabau. Sumatera Barat: Bundo Kanduang 
Provinsi Sumatera Barat.

Trijoto. (2010). Mengenal dan Membuat Motif Batik Menggali Sumber Inspirasi Pembuatan Motif Batik. Yogyakarta: Gama Media.

Tuwu, D. (2018). Peran Pekerja Perempuan Dalam Memenuhi Ekonomi Keluarga: Dari Peran Domestik Menuju Sektor Publik. Al-Izzah: Jurnal Hasil-Hasil Penelitian.

https://doi.org/10.31332/ai.v13i1 .872

Vernanda, W. (2018). Sejarah Industri dan Perdagangan Batik Kota Padang. Universitas Andalas.

Wibowo, D. E. (2011). Dan Kesetaraan Gender. 3(1), 356-364.

Zed, M. (1998). Sumatera Barat di Panggung Sejarah 1945-1995. Jakarta: Sinar Harapan. 